\title{
Work Volition and Career Adaptability as Predictors of Employability: Examining a Moderated Mediating Process
}

\author{
Jung Eon Kwon $\mathbb{D}$ \\ Department of Career and Education Consulting, Cyber Graduate School, Joongbu University, 305, \\ Dongheon-ro, Deogyang-gu, Goyang-si, Gyeonggi-do 10279, Korea; eoniroki@joongbu.ac.kr
}

Received: 3 November 2019; Accepted: 9 December 2019; Published: 11 December 2019

\begin{abstract}
Slow economic growth and cost reduction have caused a global increase in employment insecurity. For university students in the process of preparing for employment, these conditions can be a source of enormous stress. The effort to improve the employability of university students who experience difficulties in seeking a job and developing a career, therefore, becomes consequently meritorious. In order to provide new findings of the key antecedents affecting employability, this study investigates the dynamics of work volition and career adaptability. Employability is predicted by integrating career adaptability, which originated in career construction theory, and work volition, which originated in the psychology of working framework. To test the research hypotheses, survey data were collected from 251 students registered at three universities in South Korea and analyzed using a structural equation model and Hayes' process macro. Results indicated that the direct effect of work volition on employability and its indirect effect through career adaptability were significant. Next, the mediation effect of career adaptability between work volition and employability was varied positively by work volition. These results provide practical implications for efforts aimed at increasing the employability of university students and, as such, present a foundation for contribution to ensuring sustainable employability.
\end{abstract}

Keywords: work volition; career adaptability; sustainable employability; sustainable careers

\section{Introduction}

During the transition from adolescence to adulthood, university students are faced with the important task of choosing a career. Because deciding on a first job can influence the overall direction and value of future careers, systematic career preparation is required [1,2]. In traditional career theory (e.g., $[3,4])$, career preparation revolves around an individual finding appropriate employment through rational evaluation of their interests and abilities. However, the problem is that it categorizes the individuals' interests and job qualifications based on predefined standards and then simply associates them to an occupation group that is characterized by similar aptitudes and interests [5]. This model seems less relevant in the current economic climate, as persistent changes in the structure of the labor market caused by the effects of slow economic growth make it increasingly difficult to establish specific goals and plans and implement them. The pressure of employment insecurity has grown due to incessant restructuring coupled with an increase in the unemployment of young adults, and the number of temporary employees [6].

Furthermore, the recent surges in technological innovation and keen competition between companies have created a demand for job-seekers possessing practical efficacy in a multitude of functions and with a wide range of experiences. The question of how to continually secure a job and enable economic activities has, now more than ever, become apposite not only for society but 
for individuals as well [7]. Such changes in the corporate environment demand a more flexible labor market, which in turn necessitates individuals transform their perception of what a career is. Recently, rather than focusing on planning and rationality, emphasis has been placed on competence in developing flexible adaptations for enduring uncertainty and ambiguity. The traditional concept of employment, considered important in past industrial societies, is being replaced by the concept of sustainable employability $[8,9]$.

Today, career success focuses more on employability in the labor market and the psychological satisfaction felt in one's career, rather than higher wages or faster promotions in an organization or occupation [10]. In academic research (e.g., [9,11,12]), sustainable employability refers to one's capacity to maintain a lifelong stable state of employment preparedness. The concept of employability refers to the capability of an employee, not employer, and it can be understood as describing those characteristics or competences of an individual that makes employment feasible [13]. In other words, employability is the ability to exploit one's own potential to maintain sustainable employment security [14], and it refers to long-term career success [15].

Although the employability of university students has become imperative, universities do not provide adequate programs enhance employability. To address this apparent oversight, this research aims to investigate work volition and career adaptability as antecedents for strengthening the employability of university students, and enabling them to cope with the deterioration in the job environment. The concept of lifelong and assured employment enjoyed in the past has mostly disappeared. In the new paradigm, an individual takes a leading role in designing their own career and has to be able to continually adapt. Therefore, work volition and career adaptability are concepts that have become increasingly important in career development. However, to date, no studies have investigated work volition and career adaptability in combination, as predictors of employability.

Work volition refers to the will to make job-related decisions on one's own despite external constraints [16]. In real career activities, university students need to make compromises and experience frustrations caused by a confusion of values, indecision, and external constraints, among others [17]. Work volition is the will to develop and achieve career goals by overcoming these difficulties, together with the belief that future career opportunities will be available. Because of these characteristics, work volition has emerged as a factor that positively influences academic satisfaction [18,19], job satisfaction [20], and life satisfaction [21].

Career adaptability is the dynamic competence to change one's emotion, thought, and behavior to deal with uncertainty in the rapidly changing job environment [22,23]. In other words, it is the level of readiness to respond positively and actively in anticipation of future situations that are difficult to predict, rather than maintaining a coping capacity limited to the current stage of career development. Career adaptability is important for career search, satisfaction, and performance outcomes as it encourages individuals to adapt to environmental demands, which are difficult to predict [24]. Furthermore, career adaptability has recently been attracting attention as a factor closely related to an individual's happiness [25], employability skills [26], and career success [27].

The purpose of this research is to investigate the structural influence of the relationship between work volition and career adaptability, on the employability of university students, and to derive implications that help university students make rational decisions in the harsh labor market. This study, on the employability for university students who experience difficulties in seeking a job, is therefore a worthwhile endeavor. Furthermore, the academic significance of this study is found in the integration of two previously independent theories, i.e., work volition and career adaptability, as antecedent factors of employability. In addition, because these two factors contain rapidly changing social context perspectives, this study's results are expected to contribute significantly to the practical improvement of employability. 


\section{Theoretical Background and Research Hypotheses}

\subsection{Employability}

Employability is the characteristic or qualification that enables the employment of an individual. Most current definitions of employability emphasize the individual perspective [28]; however, definitions of the concept and its components have been largely contextual, depending on the scholar and time that produced them. The academic study of employability began in the 1950s; the term is a compound word combining "employ" and "ability" and can be interpreted as the "ability to employ" or the "ability to be employed." In other words, the concept of employability differs depending on whether the agent of activity that increases the employability is a society and an organization, or an individual [29].

The former interpretation incorporates the concept of improving an employment index such as the unemployment rate, from a policy perspective, by intervening in the labor market [14]. It does not stop at increasing the employment index but also focuses on attaining and maintaining sustainable employment for senior citizens, the disabled, and the disadvantaged who have difficulty in participating in the labor market [30]. This perspective, one that previously pursued employment security, formed the mainstream of early studies into employability. These studies, mostly based in Europe, endorsed opportunities for vitalizing government employment support for companies or technical education for job seekers.

By contrast, most research on the latter has been centered in North America since the late 1990s and focuses on the abilities of employed people [31]. The definition of employability has evolved into being associated with the competence of an individual that adapts to the rapidly changing industrial environment. As career development and industrial psychology theories were combined, the study of employability attempted to describe the knowledge, skill, and adaptability that contribute to the successful career and long term employment of an individual [28,32]. They encompassed sustainable career development and job planning by also dealing with overall decision-making in the case of a mismatch between the job-seeker's ability and the labor environment [33].

As such, employability is a construct built by the multi-dimensional properties of the interaction between an individual and the social environment. Llinares Insa et al. [34] propose the need for a holistic vision based on the bioecological model, and systematize it into individual, organizational and contextual elements. They emphasize the simultaneous effect of these three elements on employability. Thus, the concept of employability is subjected to debate and is not easy to measure.

Fugate et al. [13] define employability as a person's competence for identifying their job or career opportunities and responding proactively to realize them. This definition emphasizes a self-initiated competence needed for discovering and learning skills and knowledge directly required in the labor market. Watts [35] points out that a person's career should be developed, managed, and maintained for the long-term to attain sustainable employability. In other words, the measurement of employability does not end with obtaining a first job, but is the competence of being in an employment-ready state that enables one to continually move to appropriate jobs when one chooses to. The concept of employability is thus expanding to incorporate a future-oriented perspective that focuses on continuous career development by transcending one's current competencies.

Meanwhile, subjective perception, that is, in what way and how seriously a stakeholder perceives employability, is also important [36]. From this perspective, studies on self-perceived employability in terms of the sustainable career development of individuals have been actively conducted (e.g., [6,8,37-39]). Although an individual's perceived level of employability may not be linked to actual employment, empirical studies repeatedly show a positive correlation between the level of perceived employability and the possibility of successful employment. Finally, career experts accept the opinion that how an individual perceives their employability is very important for career development and employment success. Rothwell and Arnold [36] explain employability as the ability that shows one's potential through continuous employment attained over a whole 
lifetime. Vanhercke et al. [37] define perceived employability as the degree to which one feels that they can leave the current organization that they belong to and be employed in a different organization within a reasonable amount of time. This is because a high level of perceived employability positively strengthens job search-efficacy, allowing active and effective engagement in job search activities $[8,40]$. Ultimately, employability includes not only work-related knowledge and skills that enable the continuous employment of an individual in the labor market but also active adaptability and execution ability that are used to understand the changes in the environment and circumstances and attain sustainable employment in them.

\subsection{Career Adaptability}

Because of the rapidly changing economic environment, the ability to respond and adapt flexibly to changes in career selection and development has become a highly sought after skill set. Particularly, people in a modern society have to overcome the enormous stress induced by high unemployment rates and employment insecurity to achieve a high level of performance [24]. Career adaptability is prepared volition or competence that responds to uncertainty by changing one's emotion, thought, and behavior as needed, even in the face of unpredictable changes [41]. In the past, when the job environment was relatively stable, career development was focused on career maturity, such as job promotions or increasing one's knowledge. However, recent studies on career development have focused on the depth of career adaptability in terms of dynamic competencies.

Career adaptability was first proposed by Super and Knasel [42] and systematized by Savickas [22,23]. Super and Knasel [42] hold the view that careers mature as an individual's age progresses. This is viewed from the perspective of the individual's entire life. They argue that because adults perform different roles in diverse environments, there are differences among individuals, and the concept of maturity is inappropriate as a predictable and normative growth standard. They propose career adaptability as an alternative concept of describing adult career development.

Savickas' career construction theory [23] illustrates how an individual constructs a career on their own by giving meaning to behaviors and vocational experiences related to their career. Because Savickas re-conceptualizes the major concept of Super's career development theory to fit the modern era based on social constructionism, his argument is called a 21st century extension of Super's theory [43]. He postulates that development is attained through a process of adaptation within a context rather than the maturity of inner structure. He emphasizes that a career is a process of satisfying social demands and of responding to social tasks. Above all, because the environment shapes the individual, and the individual also, in turn, shapes the environment; he accords importance to an individual's developmental elasticity and improvement of perception as the main agent of development. A certain type of career is constructed subjectively based on biographical reflection according to various career behaviors, rather than constructed by the sum of experiences related to work or a fitting of the person to the environment from an objective perspective.

Career adaptability based on the career construction theory is the ability of an individual to satisfy their vocational requirements according to their desired career direction [44]. It includes coping with present or future vocational developmental tasks, work or job change, and psychological difficulty [45]. In career construction theory, an individual realizes their self-concept through career adaptation, and that becomes a process of renewing their career. Vocational preference or aptitude focuses on the selection of a specific job, but career adaptability emphasizes the process of overcoming challenges in the course of building a career. An individual gives meaning to the process through career adaptability while completing their own career and realizing their self-concept in vocational roles.

Savickas [23] divides career adaptability into four categories: Concern, curiosity, control, and confidence. Concern refers to the tendency to plan career development, connecting the past, present, and future while maintaining a positive perception of one's vocational future. When there is a lack of concern, no plan is formed, and pessimism ensues. Curiosity refers to the tendency to systematically search for a fit between oneself and the vocational world. This is the explorative attitude of individuals 
seeking more information to gain deeper insight into themselves and their jobs. An important aspect of curiosity is that reality and objectivity are evoked when making a selection to match oneself with a job through such an explorative attitude. Control means that an individual makes a decision on their own initiative, autonomously, by taking responsibility for building their own career. Confidence refers to an individual's confidence in their success when faced with an obstacle, problem, or challenging task.

As discussed above, career adaptability is competence in adapting smoothly in an uncertain career environment [27]. Along with the scarcity of quality jobs due to slow economic growth, problems of mismatching have proliferated and consequently, more emphasis is now placed on career adaptability. If career adaptability is strong, even in an uncertain and insecure environment, one participates actively in unofficial learning as well as formal learning to acquire the knowledge, skills, and competence required by a new environment $[1,46,47]$. Through these activities, the possibility of seizing an employment opportunity increases. Such characteristics indicate a high correlation between employability and career adaptability. Therefore, it is predicted that even for a university student who has not yet moved into the vocational world, employability will be increased more than what is usually anticipated if career adaptability is strong.

\subsection{Work Volition}

Careers have been dealt with from the perspective of rational person-environment fit $[20,48]$. Under the premise that every person can freely choose the most suitable career, an ideal career should be chosen that reflects one's interests, values, and aptitude in order to pursue maximum job satisfaction. However, the majority of people hardly enjoy sufficient freedom in deciding on a desired career because of their specific conditions and contexts [49]. In other words, the selection of a realistic career is limited by compromising to suit various environmental constraints [50].

As such, work volition is the ability to perceive that a career-related decision can be made correctly despite external constraints [16]. The dictionary defines volition as "the will to freely choosing an action for a certain purpose according to inner motivations or ideals without external limitations or constraints." Work volition reflects this in the context of job and work. Based on Blustein's concept [49,51], Duffy et al. [16] define work volition as "the perceived capacity to make occupational choices despite constraints."

Blustein $[49,51]$ proposes the seriousness and importance of work volition in his "Psychology of Working Framework." According to the psychology of working framework, work is a vehicle that allows an individual to express their identity through socially and economically meaningful production activities in the community to which they belong [52]. Specifically, work elicits life satisfaction by satisfying desires for survival, relatedness, and self-determination. From this perspective, work volition is an important source of overall wellness, as well as being one of the most essential domains in the life of an individual.

According to Duffy et al. [16], a person with high work volition perceives that they have many job opportunities with few external and structural limitations, believing that they can overcome these limitations. By contrast, a person with low work volition perceives few job opportunities. Such a person perceives high external and structural limitations and regards circumstance, in which they have to choose a job irrespective of personal preference, as a source of pressure.

Work volition is highly related to basic individual resources such as psychological capital [53] and has a direct influence on a variety of career outcomes [54,55]. Work volition also showed positive correlations with positive affect [56], life satisfaction [21], academic satisfaction in university students [19], and job satisfaction in workers [57].

Finally, the work volition to achieve career goals, from a motivation perspective, is highly important for career selection. Workers with high work volition treat their work as a vocation and easily derive meaning from it [58]. Furthermore, work volition becomes a critical element for a high quality of life. Considering these characteristics of work volition, a positive correlation with employability is expected. 


\subsection{Research Model and Hypotheses}

A few studies investigating the relationship between work volition and career adaptability have consistently reported a close or mutually reciprocal relationship [52]. However, there are mixed results about the direction of influential power between them. Although some studies saw career adaptability as antecedent to work volition, this study considers that career adaptability as it relates to career development is affected by work volition. Recently, Autin et al. [59] also investigated the influence of social position on career adaptability in a longitudinal study and demonstrated a significant mediation effect by setting work volition as an antecedent variable of career adaptability. Because a person with high work volition feels that there are few career barriers and perceives a high level of control, there is a strong possibility that they will engage in flexible career activities. The above discussions regarding the relations among work volition, career adaptability, and employability suggest that career adaptability may serve a mediator in the effect of work volition on career adaptability.

Hypothesis 1 (H1). University student's career adaptability will mediate the relationship between work volition and employability.

In addition, work volition can act as a conditional context of career activity in the relationship between career adaptability and employability. Work volition is closely related to environmental factors such as social position and career barriers and corresponds to personal psychological characteristics, which are relatively difficult to change [56]. Because of these characteristics, work volition is sometimes applied as a conditional context variable that controls the influence of work self-efficacy and perceived organizational support in work satisfaction studies [57]. In other words, work volition can be applied as an environmental condition for career adaptability and employability as well. Work volition will moderate the relation between career adaptability and employability, such that this relationship is intensified as work volition increase. Accordingly, an effect of work volition that controls the influence of career adaptability on employability was assumed.

Hypothesis 2 (H2). A university student's work volition will control the relationship between career adaptability and employability.

Figure 1 illustrates a research model for the structural causal relationships according to the two hypotheses of this study. It shows that the effect of work volition on employability is more strongly mediated by career adaptability for those with higher rather than lower levels of work volition. This model corresponds to Model 74 of the conditional process models presented by Hayes [60].

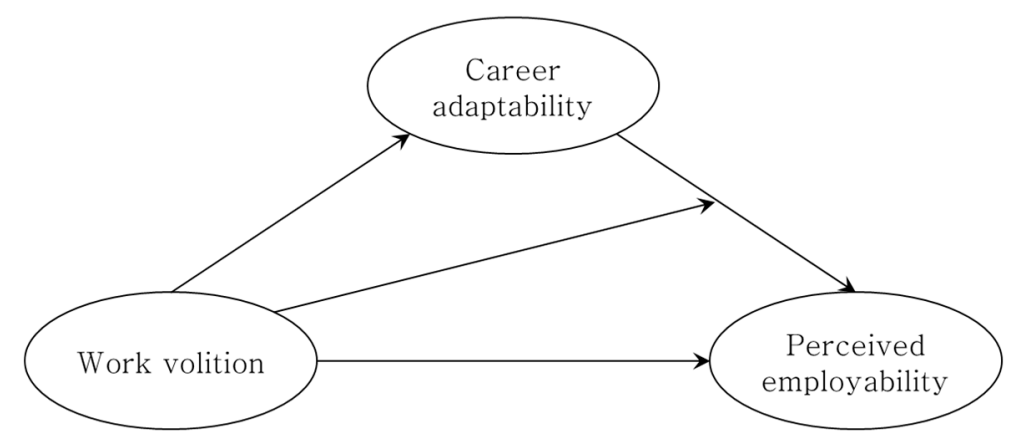

Figure 1. The research model. 


\section{Materials and Methods}

\subsection{Measures}

A self-reported questionnaire was used as the measurement method to gauge the accuracy of the research hypotheses. To measure the major variables of employability, career adaptability, and work volition, questions with reliability and validity proven in previous studies were used with a 6-point Likert scale ( $1=$ strongly disagree, $6=$ strongly agree), which ensures the validity of composition and improves the reliability [61]. The operational definition and the questions for each of the major variables follow.

For employability, Rothwell and Arnold's self-perceived employability scale [36] composed of 16 questions was used. These questions have been used in many previous studies targeting university students, and include questions like "I can easily find out about opportunities in my chosen field." and "I am generally confident of success in job interviews and selection events."

For career adaptability, the career adapt-abilities scale (CAAS) was used. The CAAS consists of stable questions, the reliability and validity of which have been proven in Savickas and Porfeli [62]. It consists of 24 questions that measure the sub-factors of career adaptability, that is, concern, control, curiosity, and confidence, with six questions each. The questionnaire questions of Tak [63], for which a validation study was completed in South Korea, were used.

For work volition, the work volition scale (student version) developed by Duffy et al. [16] was used. This tool consists of two sub-factors, volition and constraint. The sub-factor, volition, consists of nine questions, which measure the ability to independently choose a career with self-efficacy. The sub-factor, constraint, consists of seven questions, which measure the conditions that hinder an individual's autonomous decision-making in terms of family, finance, and structure. A high final combined score indicates that despite constraints and limitations, the level of work volition for making career decisions is high. In this study, the internal consistency was 0.76 for volition and 0.78 for constraint, and the total internal consistency was 0.78 .

In addition to the major variables, information on the respondents' gender, school year, and university was collected, which could have an overall influence on the research hypotheses. Because aspects of this study's major variables may vary depending on the demographic dependent characteristics of respondents, the information was controlled using control variables.

\subsection{Participants}

For two months from April to May 2019, data were collected from junior and senior students of three universities located in the capital region of South Korea. Among the four-year universities with more than 5000 registered students, three universities having a relatively balanced number of students in the colleges of humanities, social studies, natural science, and engineering were selected. Two or three collaborators were recruited from the selected universities, and the investigation was conducted with their help. The students were limited to those of the junior and senior years because it is believed that those are the periods when students are more likely to show a more serious interest in career preparation and consequently, there was a high possibility that they would answer the employability questions seriously. Of the 290 distributed questionnaires, 262 responses (response rate: $90.3 \%$ ) were collected. Among them, 11 insincere respondents were excluded and the survey was analyzed for 251 respondents. The characteristics of the target respondents were as follows: $84.4 \%$ were senior students and $15.6 \%$ were junior students; $63.8 \%$ were male and $36.2 \%$ female. Furthermore, the academic majors were $54.7 \%$ humanities and social studies and $45.3 \%$ sciences and engineering, showing little difference between the major proportions. Therefore, it was determined that the respondents were appropriate research targets. 


\subsection{Data Analysis}

The established hypotheses and the research model were analyzed using a structural equation model using SmartPLS and Hayes' process macro [60]. The process macro is a more precise and effective method of checking the relationship between variables and is used broadly in social science research [64]. Prior to verifying the research hypotheses, a non-response bias, common method bias, and confirmatory factor analysis were performed. This was because even though the tool had already been verified, it was necessary to minimize the problems following the question adaptation and to ensure the structural stability of the research model.

The existence of a non-response bias was checked by comparing $25 \%$ of the data collected in the early stage and $25 \%$ collected in the latter stage. A $t$-test was performed to check for differences in employability, career adaptability, and work volition in the extracted data, but no significant difference was found and considering the high response rate of $90.3 \%$, it was determined that the non-response bias was weak in the collected data.

This study's survey method might result in a common method bias because an individual person answered all variables. Therefore, verification was performed using Harman's single factor test. Because the dispersion that explained the first factor having an eigenvalue of 1.0 or higher, which was derived using a non-rotated principal component analysis, remained at $35.6 \%$, it was determined that the distortion problem caused by the common method bias was not serious. Moreover, in the results of the confirmatory factor analysis, which incremented the number of factors from that of the independent model, the model that set up three factors had the highest fit and satisfied the criteria.

In the confirmatory factor analysis, four questions with a path-coefficient of less than 0.5 were removed. As a result, because the standard loading value of every factor was higher than 0.5 , it was determined that the validity of concept was ensured. The composite reliability (CR) was $0.848-0.962$, showing a high level. The average variance extracted (AVE) was 0.519-0.905. Because the CR and the AVE satisfied the usual criteria (CR > 0.7 and AVE $>0.5$ ) proposed by Bagozzi and Yi [65], convergent validity was ensured. The squared multiple correlation (SMC) and the AVE of latent variables were compared to check the discriminant validity. Because the AVE was larger than the SMC in every case, the discriminant validity was ensured. In addition, the values of the reliability coefficients were all higher than 0.7 , indicating that there was no problem in the reliability of the measurement tool.

After verifying the reliability and validity of the measurement tool, the mediating and moderating effects inherent in the research model were comprehensively verified based on analysis using the SPSS PROCESS macro. To verify the mediated moderation effect, the Process Macro's Model 74 was used, and repeated sampling for bootstrapping was performed 10,000 times. To investigate in which area the moderation effect was significant, according to the level of the moderating variable, floodlight analysis using the Johnson-Neyman method $[60,66]$ was performed for whole ranges of moderating variables. The statistically significant moderation effect was visualized through simple slope analysis to check its shape.

\section{Results}

Prior to hypothesis testing, the descriptive statistics, including the means, standard deviations, and correlations among the variables, were calculated using SPSS (See Table 1). As expected, the relation between work volition and career adaptability was significant $(\mathrm{r}=0.26, p<0.01)$. Furthermore, perceived employability was positively correlated with career adaptability $(r=0.49, p<0.01)$ as well as with work volition $(r=0.33, p<0.01)$. These outcomes mean that the hypothesized relations among work volition, career adaptability and perceived employability have nomological validity. All correlation coefficients less than 0.60 do not suggest multicollinearity as a problem. 
Table 1. Descriptive statistics.

\begin{tabular}{lllllllllll}
\hline & Mean & SD & $\mathbf{1}$ & $\mathbf{2}$ & $\mathbf{3}$ & $\mathbf{4}$ & $\mathbf{5}$ & $\mathbf{6}$ & $\mathbf{7}$ & $\mathbf{8}$ \\
\hline 1. Gender & 0.52 & 0.50 & & & & & & & & \\
2. University1 & 0.34 & 0.31 & 0.05 & & & & & & \\
3. University2 & 0.48 & 0.46 & -0.03 & -0.05 & & & & & \\
4. College1 & 0.24 & 0.42 & 0.05 & 0.10 & 0.05 & & & & \\
5. College2 & 0.28 & 0.45 & -0.09 & -0.31 & -0.27 & -0.29 & & & & \\
6. College3 & 0.23 & 0.42 & 0.06 & 0.20 & -0.02 & 0.19 & -0.06 & & & \\
7. Work volition & 4.87 & 1.04 & 0.09 & 0.39 & 0.20 & 0.37 & -0.31 & 0.16 & & \\
8. Career adaptability & 4.52 & 1.26 & -0.02 & 0.16 & 0.05 & 0.18 & -0.12 & -0.03 & 0.26 & \\
9. Perceived employability & 4.38 & 1.01 & 0.05 & 0.18 & 0.06 & 0.20 & -0.16 & 0.04 & 0.33 & 0.49 \\
\hline
\end{tabular}

$\mathrm{N}=251$. Gender, university, and college were dummied. All correlation coefficients above $|0.124|$ are significant at the 0.05 level, and those above $|0.162|$ are significant at the 0.01 level.

The hierarchical regression analysis that was conducted included five separate models, as presented in Table 2. Demographic variables, including gender, universities, and colleges, were controlled for in all analyses. The effects of the control variables on career adaptability $\left(\mathrm{R}^{2}=0.063 ; \mathrm{F}=2.25, p<0.05\right)$ and perceived employability $\left(\mathrm{R}^{2}=0.091 ; \mathrm{F}=2.52, p<0.05\right)$ were significant in Model 1 and 3. Work volition served as a significant and positive predictor for career adaptability (Model 2: $\beta=0.24, p<0.05$ ) and perceived employability (Model 4: $\beta=0.29, p<0.05$ ). In Model 4 , career adaptability also had the significant impact on perceived employability $(\beta=0.42, p<0.01)$. In line with Hypothesis 1 , these significant relations supported the partial mediation of career adaptability between work volition and perceived employability.

Table 2. Results of hierarchical regression analysis.

\begin{tabular}{|c|c|c|c|c|c|}
\hline & \multicolumn{2}{|c|}{ Career Adaptability $^{a}$} & \multicolumn{3}{|c|}{ Perceived Employability ${ }^{b}$} \\
\hline & Model 1 & Model 2 & Model 3 & Model 4 & Model 5 \\
\hline Gender & 0.01 & 0.01 & 0.03 & 0.01 & 0.02 \\
\hline University1 & $0.14^{*}$ & 0.12 * & $0.15^{*}$ & $0.12 *$ & 0.10 \\
\hline University2 & 0.03 & 0.02 & 0.04 & 0.03 & 0.03 \\
\hline College1 & $0.15^{*}$ & 0.11 & $0.15^{*}$ & 0.13 * & 0.09 \\
\hline College2 & -0.08 & -0.03 & $-0.13 *$ & $-0.12 *$ & -0.11 \\
\hline College3 & -0.01 & -0.01 & 0.03 & 0.03 & 0.01 \\
\hline Work volition & & 0.24 * & & 0.29 * & $0.23 *$ \\
\hline Career adaptability & & & & $0.42 * *$ & $0.38^{* *}$ \\
\hline Work volition $\times$ Career adaptability & & & & & $0.22 *$ \\
\hline R-squared & $0.063 *$ & $0.113^{* *}$ & $0.091 *$ & $0.374 * *$ & $0.401 * *$ \\
\hline$\Delta R$-squared & & 0.050 * & & $0.283^{* *}$ & $0.027 *$ \\
\hline
\end{tabular}

The interaction term multiplying work volition by career adaptability was significant $(\beta=0.22$, $p<0.05$ ) in Model 5. It indicated that work volition exerted a moderating effect on the relation between career adaptability and perceived employability. The simple slopes shown in the graphic representation of the moderating effect of work volition are displayed in Figure 2, following the procedure outlined by Aiken and West [67]. The higher the work volition, the stronger the relation between career adaptability and perceived employability became. 


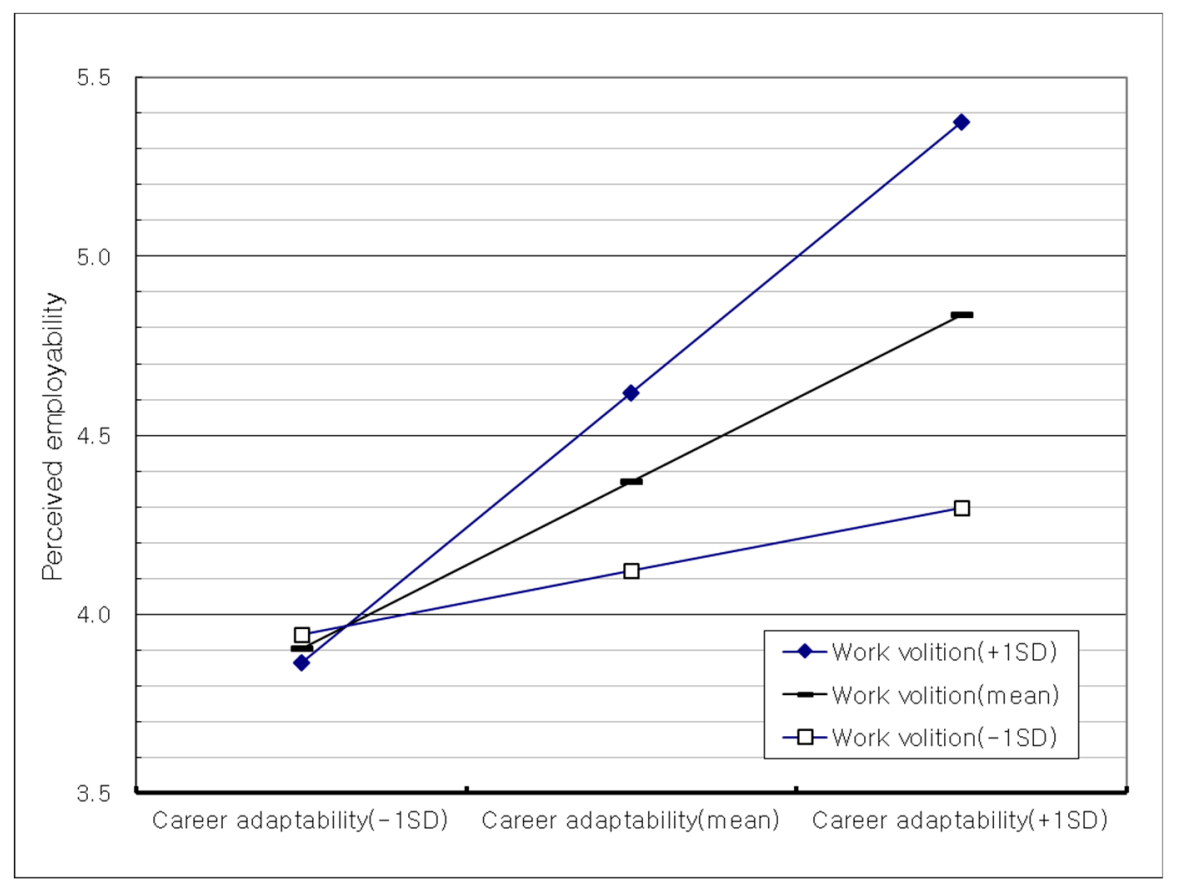

Figure 2. The moderating effect of work volition on career adaptability and perceived employability.

A more detailed effect was estimated by Hayes' PROCESS macro for moderated mediation $[60,68]$. The conditional process analysis was based on 8000 bootstrap samples. The result was confirmed by the pick-a-point approach using representative values (+1SD, mean, $-1 \mathrm{SD})$ of the moderator. In Table 3 , the indirect impact on perceived employability via career adaptability was stronger the higher the work volition $(B=0.15, S E=0.07,95 \% C I=[0.03,0.28])$ rather than at a lower $(B=0.04, S E=0.06$, $95 \% \mathrm{CI}=[-0.08,0.15])$ work volition. The index of moderated mediation did not include zero in the confidence interval (Index $=0.06, \mathrm{SE}=0.03,95 \% \mathrm{CI}=[0.01,0.11]$ ), which implies that the indirect effect could vary significantly with work volition [68].

Table 3. Results of conditional process analyses.

\begin{tabular}{ccccc}
\hline & B & SE & LLCI $^{\mathbf{a}}$ & ULCI $^{\mathbf{b}}$ \\
\hline $\begin{array}{c}\text { Index of moderated mediation } \\
\text { Conditional indirect effect }\end{array}$ & 0.06 & 0.03 & 0.01 & 0.11 \\
$\quad$ Work volition(+1SD) & 0.15 & 0.07 & 0.03 & 0.28 \\
Work volition(mean) & 0.09 & 0.04 & 0.01 & 0.17 \\
Work volition(-1SD) & 0.04 & 0.06 & -0.08 & 0.15
\end{tabular}

a LLCI: Lower limit of bias-corrected bootstrap 95\% confidence interval. ${ }^{\text {b }}$ ULCI: Upper limit of bias-corrected bootstrap $95 \%$ confidence interval.

The floodlight analysis using the Johnson-Neyman technique [60,66] derived values of work volition that show a significant, conditional indirect effect, shown in Figure 3. The solid line indicates the corresponding effect values relating work volition to perceived employability and the dashed lines are at a $95 \%$ confidence interval. The confidence interval, containing zero for the work volition range below -0.07 , means that the indirect effect of work volition on perceived employability through career adaptability is not significant. On the other hand, the effect was significantly different from zero for the rest of range of work volition. Because the mediating effect of career adaptability differed according to the level of work volition, this result supports Hypothesis 2. 


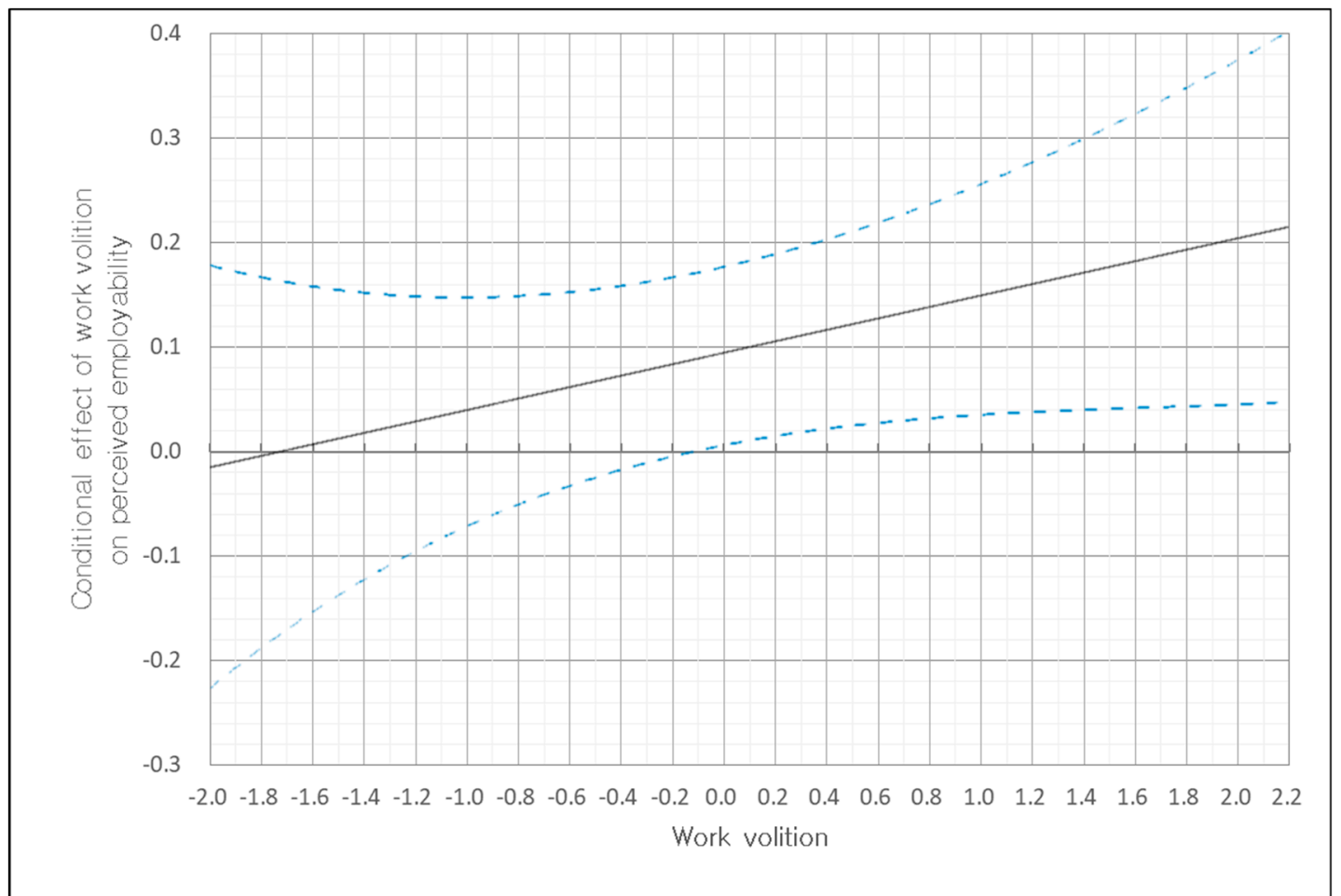

Figure 3. The indirect effect of work volition on perceived employability via career adaptability.

\section{Discussion}

\subsection{Findings and Implications}

Work is a means of self-realization and plays a pivotal role in human life. A career closely related to work experience is the process to fulfill this existential realization. Therefore, employability, which reflects an individual's competence in searching for suitable work and building a meaningful career, has profound implication on their life. However, because of the unemployment crisis, caused by deteriorating socioeconomic conditions, university students have lost confidence in their ability to pursue ideal careers.

The majority of studies in the past emphasize objective career success, focusing on employment, salary, and job promotion, among others; by contrast, recent studies pay attention to psychological successes such as career satisfaction or employability, however, there are very few articles that investigate employability by targeting university students. Therefore, this study examined the dynamics of career adaptability and work volition as predictors that explain the employability of junior and senior university students awaiting employment. This approach, to integrate career construction theory and the psychology of working framework while investigating employability, has considerable academic significance because this study paves the way for expanding the breadth of career success research as follows.

First, the significant direct effect of work volition on employability means that psychological willingness to pursue a desired career without being bounded by poor conditions has a positive effect on employability. This implies that work volition is a useful variable for intervention in the careers of university students experiencing structural and practical career barriers. Consultants assisting in the career development of university students should help students maintain positive perspectives regarding themselves and their future. In addition, it is important to discuss how to cope with specific career barriers, and to improve the willingness to achieve a desired career.

By itself, however, work volition is limited to not completely resolving stress or anxiety related to employment. When a perceived career barrier is relatively high, depression, anxiety, and decreased 
self-efficacy are experienced. Accordingly, it is necessary to present a specific behavior direction, so that students can not only accept productively the uncertainty and ambiguity of the environment but also control and develop their own careers. This study presents career adaptability as a factor that could aid in this endeavor.

Second, the results verifies the significant mediating effect of career adaptability on the relationship between employability and work volition. In other words, it was shown that work volition has an indirect effect on employability because career adaptability is the mediating factor. This result is consistent with the basic concept of career adaptability and can be interpreted through career construction theory, which is the foundation for career adaptability. Career adaptability encompasses the whole process of planning, preparing, and adapting one's work and life to maintain a successful career. According to the career construction theory, a career is not a fixed result but a process of continuously building results through activities that a person gives meaning to, in trying to achieve a goal. In other words, career adaptability is developed as the propensity and the attitude of an individual to be expressed in practical actions, and these experiences are continuously accumulated. The task of shedding light on a person's career activities and thinking about how to materialize their life goals in the future, from the perspective of career adaptability, will be useful for developing the big picture regarding career objectives.

Career adaptability is not a one-off event aimed at discovering one job opportunity but is an on-going lifelong process of materialization, one founded on pursuing a life goal based on a clear self-understanding. In this career development process, employability can be improved by helping university students recognize that anxiety and stress are natural and necessary to gain enough confidence for the successful execution of career tasks. From this perspective, a university can provide various opportunities for students to develop a sufficient level of career adaptability so that they can clarify their ultimate goals and work values.

Third, because work volition corresponds with relatively stable psychological characteristics, it can also act in the conditional context of career activity. This hypothesis is confirmed by the significant moderating effect of work volition on the relationship between career adaptability and employability. In other words, the positive influence of career adaptability on employability is further strengthened by work volition. Career adaptability has a larger influence on the employability of students with high work volition than those with low work volition. This means that the influence of career adaptability on employability is smaller for students with low work volition than those with high work volition.

As shown above, work volition and career adaptability have a significant influence on employability through complex interactions rather than as separate variables. We should especially pay attention to the indirect effect of work volition on employability through career adaptability. This is because of the practical implication of presenting a specific direction for the development and growth of work volition. Until now, because work volition is an inherent psychological propensity that requires time to change, there has been no specific direction for its development. Based on this study's results, it is found that focusing on career adaptability is a more effective direction for improving the effects of work volition.

If the dynamic between work volition and career adaptability revealed in this study is employed as the major focus of an employability improvement program, it would greatly benefit the practical employment of university students. Based on this, a university can analyze its career development activities to focus on the students and effectively search for desirable alternatives. As a result, an increase in the practical effectiveness of policies and educational alternatives to positively affect employability will be seen. This aims at the career development and organization adaptation of university students.

\subsection{Limitations and Future Directions}

The limitations of this study and suggestions for follow-up studies are as follows. First, this study relied on cross-sectional data collected in a survey. Although the research hypotheses were established based on theoretical grounds, there are limitations in the causal reasoning of this study in a strict sense. 
In future studies, it is necessary to collect data through a variety of qualitative research such as in-depth interviews, personal interviews, and observation reports in addition to the self-reported questionnaire.

Particularly, in career construction theory, "career" should be understood as the process of forming a career by giving meaning and direction to career behavior based on the subjective experiences and values of an individual. Therefore, qualitative research is required for more specific findings regarding the formation of employability based on career adaptability. Although qualitative research has limitations in that the subjectivity of the researcher is reflected in its findings, and it is limited to only certain cases, if an integrated study is attempted based on the results of this study, more specific implications will be derived.

Second, this study's targets were limited to junior and senior students from three universities located in the capital region of South Korea. Considering the gaps in university locations, academic departments, and the number of registered students, among others, convenience sampling was used to control the exogenous variables. Because of this, the generalization of applying these results to all university students is limited. Future studies should increase the feasibility of generalization by selecting research targets using a more precise method. In addition, if the research targets are expanded to include adults and workers, it will be possible to obtain more important results regarding the following: Implications of work volition and career adaptability from the sustainable employability perspective for continuously maintaining employment in the vocational world as well as transitioning from a university to the vocational world; and concrete methods of applying the work volition and the career adaptability concepts to career development.

Lastly, this study focused on employability as an indicator of career success. To obtain more theoretical and practical implications, follow-up studies should use a variety of consequent variables. For example, future studies should be conducted in terms of career development regarding whether the employability perceived by university students actually had an influence on their hiring, work satisfaction, or job mobility after being employed. This is because the transition from university and establishment of an individual as part of society does not just stop at getting a job; adaptation in an organization after employment and switching to a better job in a better organization are also important factors. Careful consideration of the relations between these factors have a deep theoretical and practical significance on helping a person advance employment. If such follow-up studies are accumulated, it will be possible to propose effective initiatives for the development of sustainable employability across the whole lifespan including not only the first employment, but also work and job changes.

\section{Conclusions}

In the present research, we investigated the relation between work volition and career adaptability as important precursors of employability. This theoretical research model integrated the "career construction" theory of career adaptability and the "psychology of working" framework of work volition with the aim of enriching our understanding of employability. The integrative approach of two theories in different domains signifies step forward in the theoretical advancement of employability. The findings indicate that the direct effect of work volition on employability and its indirect effect via career adaptability were significant. We further confirmed work volition also moderated the mediating effect of career adaptability on employability. These results should be of practical value for university students who experience difficulties amidst the uncertainties of the harsh labor market to promote their employability and for career counsellors to understand the psycho-social processes of building employability. Future studies are needed to explore the various components of employability to ensure sustainable employability.

Funding: This research was funded by Joongbu University, grant number 2018-03-80.

Conflicts of Interest: The author declares no conflict of interest. 


\section{References}

1. Atitsogbe, K.A.; Mama, N.P.; Sovet, L.; Pari, P.; Rossier, J. Perceived employability and entrepreneurial intentions across university students and job seekers in togo: The effect of career adaptability and self-efficacy. Front. Psychol. 2019, 10. [CrossRef] [PubMed]

2. Tymon, A.; Harrison, C.; Batistic, S. Sustainable graduate employability: An evaluation of 'brand me' presentations as a method for developing self-confidence. Stud. High. Educ. 2019. [CrossRef]

3. Tiedeman, D.V.; O'Hara, R.P. Career Development: Choice and Adjustment; College Entrance Examination Board: New York, NY, USA, 1963.

4. Hall, D.T. A theoretical model of career subidentity development in organizational settings. Organ. Behav. Hum. Perform. 1971, 6, 50-76. [CrossRef]

5. Pan, J.; Guan, Y.; Wu, J.; Han, L.; Zhu, F.; Fu, X.; Yu, J. The interplay of proactive personality and internship quality in chinese university graduates' job search success: The role of career adaptability. J. Vocat. Behav. 2018, 109, 14-26. [CrossRef]

6. Magnano, P.; Santisi, G.; Zammitti, A.; Zarbo, R.; Di Nuovo, S. Self-perceived employability and meaningful work: The mediating role of courage on quality of life. Sustainability 2019, 11, 764. [CrossRef]

7. Bernstrøm, V.H.; Drange, I.; Mamelund, S.E. Employability as an alternative to job security. Pers. Rev. 2019, 48, 234-248. [CrossRef]

8. Chiesa, R.; Fazi, L.; Guglielmi, D.; Mariani, M.G. Enhancing substainability: Psychological capital, perceived employability, and job insecurity in different work contract conditions. Sustainability 2018, 10, 2475. [CrossRef]

9. Bologa, R.; Lupu, A.-R.; Boja, C.; Georgescu, T.M. Sustaining employability: A process for introducing cloud computing, big data, social networks, mobile programming and cybersecurity into academic curricula. Sustainability 2017, 9, 2235. [CrossRef]

10. Blokker, R.; Akkermans, J.; Tims, M.; Jansen, P.; Khapova, S. Building a sustainable start: The role of career competencies, career success, and career shocks in young professionals' employability. J. Vocat. Behav. 2019, 112, 172-184. [CrossRef]

11. Van der Heijden, B.I.J.M.; Gorgievski, M.J.; De Lange, A.H. Learning at the workplace and sustainable employability: A multi-source model moderated by age. Eur. J. Work Organ. Psychol. 2016, 25, 13-30. [CrossRef]

12. Hazelzet, E.; Picco, E.; Houkes, I.; Bosma, H.; de Rijk, A. Effectiveness of interventions to promote sustainable employability: A systematic review. Int. J. Environ. Res. Public Health 2019, 16, 1985. [CrossRef] [PubMed]

13. Fugate, M.; Kinicki, A.J.; Ashforth, B.E. Employability: A psycho-social construct, its dimensions, and applications. J. Vocat. Behav. 2004, 65, 14-38. [CrossRef]

14. Hillage, J.; Pollard, E. Employability: Developing a Framework for Policy Analysis; Department for Education and Employment: London, UK, 1998.

15. Van der Heijden, B.I.J.M.; de Lange, A.H.; Demerouti, E.; Van der Heijde, C.M. Age effects on the employability-career success relationship. J. Vocat. Behav. 2009, 74, 156-164. [CrossRef]

16. Duffy, R.D.; Diemer, M.A.; Perry, J.C.; Laurenzi, C.; Torrey, C.L. The construction and initial validation of the work volition scale. J. Vocat. Behav. 2012, 80, 400-411. [CrossRef]

17. Kim, N.R.; Kim, H.J.; Lee, K.H. Social support and occupational engagement among korean undergraduates: The moderating and mediating effect of work volition. J. Career Dev. 2018, 45, 285-298. [CrossRef]

18. Duffy, R.D.; Douglass, R.P.; Autin, K.L. Career adaptability and academic satisfaction: Examining work volition and self efficacy as mediators. J. Vocat. Behav. 2015, 90, 46-54. [CrossRef]

19. Jadidian, A.; Duffy, R.D. Work volition, career decision self-efficacy, and academic satisfaction: An examination of mediators and moderators. J. Career Assess. 2012, 20, 154-165. [CrossRef]

20. Duffy, R.D.; Autin, K.L.; Bott, E.M. Work volition and job satisfaction: Examining the role of work meaning and person-environment fit. Career Dev. Q. 2015, 63, 126-140. [CrossRef]

21. Buyukgoze-Kavas, A.; Duffy, R.D.; Douglass, R.P. Exploring links between career adaptability, work volition, and well-being among turkish students. J. Vocat. Behav. 2015, 90, 122-131. [CrossRef]

22. Savickas, M.L. The theory and practice of career construction. In Career Development and Counseling: Putting Theory and Research to Work; Lent, R.W., Brown, S.D., Eds.; John Wiley \& Sons: Hoboken, NJ, USA, 2005; pp. $42-70$. 
23. Savickas, M.L. Career construction theory and practice. In Career Development and Counseling: Putting Theory and Research to Work, 2nd ed.; Lent, R.W., Brown, S.D., Eds.; John Wiley \& Sons: Hoboken, NJ, USA, 2013; pp. 147-183.

24. Bocciardi, F.; Caputo, A.; Fregonese, C.; Langher, V.; Sartori, R. Career adaptability as a strategic competence for career development: An exploratory study of its key predictors. Eur. J. Train. Dev. 2017, 41, 67-82. [CrossRef]

25. Johnston, C.S.; Luciano, E.C.; Maggiori, C.; Ruch, W.; Rossier, J. Validation of the german version of the career adapt-abilities scale and its relation to orientations to happiness and work stress. J. Vocat. Behav. 2013, 83, 295-304. [CrossRef]

26. De Guzman, A.B.; Choi, K.O. The relations of employability skills to career adaptability among technical school students. J. Vocat. Behav. 2013, 82, 199-207. [CrossRef]

27. Zacher, H. Career adaptability predicts subjective career success above and beyond personality traits and core self-evaluations. J. Vocat. Behav. 2014, 84, 21-30. [CrossRef]

28. Forrier, A.; Sel, L. The concept employability: A complex mosaic. Int. J. Hum. Resour. Dev. Manag. 2003, 3, 102-124. [CrossRef]

29. Versloot, A.; Glaudé, M.; Thijssen, J. Employability: A Multiform Labour Market Phenomenon; MGK: Amsterdam, The Netherlands, 1998.

30. McQuaid, R.; Lindsay, C. The concept of employability. Urban Stud. 2005, 42, 197-219. [CrossRef]

31. Jesser, D.L. The employability skills initiative in colorado. J. Career Dev. 1984, 11, 33-41. [CrossRef]

32. Bhaerman, R.; Spill, R. A dialogue on employability skills: How can they be taught? J. Career Dev. 1988, 15, 41-52. [CrossRef]

33. Williams, S.; Dodd, L.J.; Steele, C.; Randall, R. A systematic review of current understandings of employability. J. Educ. Work 2016, 29, 877-901. [CrossRef]

34. Llinares Insa, L.I.; Zacarés González, J.J.; Córdoba Iñesta, A.I. Discussing employability: Current perspectives and key elements from a bioecological model. Empl. Relat. 2016, 38, 961-974. [CrossRef]

35. Watts, A.G. Career Development Learning and Employability; Higher Education Academy: London, UK, 2006.

36. Rothwell, A.; Arnold, J. Self-perceived employability: Development and validation of a scale. Pers. Rev. 2007, 36, 23-41. [CrossRef]

37. Vanhercke, D.; De Cuyper, N.; Peeters, E.; De Witte, H. Defining perceived employability: A psychological approach. Pers. Rev. 2014, 43, 592-605. [CrossRef]

38. Udayar, S.; Fiori, M.; Thalmayer, A.G.; Rossier, J. Investigating the link between trait emotional intelligence, career indecision, and self-perceived employability: The role of career adaptability. Personal. Individ. Differ. 2018, 135, 7-12. [CrossRef]

39. Van Hootegem, A.; De Witte, H.; De Cuyper, N.; Elst, T.V. Job insecurity and the willingness to undertake training: The moderating role of perceived employability. J. Career Dev. 2019, 46, 395-409. [CrossRef]

40. Yizhong, X.; Lin, Z.; Baranchenko, Y.; Lau, C.K.; Yukhanaev, A.; Lu, H. Employability and job search behavior: A six-wave longitudinal study of chinese university graduates. Empl. Relat. 2017, 39, 223-239. [CrossRef]

41. Johnston, C.S. A systematic review of the career adaptability literature and future outlook. J. Career Assess. 2018, 26, 3-30. [CrossRef]

42. Super, D.E.; Knasel, E.G. Career development in adulthood: Some theoretical problems and a possible solution. Br. J. Guid. Couns. 1981, 9, 194-201. [CrossRef]

43. Amundson, N.E.; Harris-Bowlsbey, J.E.; Niles, S.G. Essential Elements of Career Counseling: Processes and Techniques, 3rd ed.; Pearson: Upper Saddle River, NJ, USA, 2013.

44. Neureiter, M.; Traut-Mattausch, E. Two sides of the career resources coin: Career adaptability resources and the impostor phenomenon. J. Vocat. Behav. 2017, 98, 56-69. [CrossRef]

45. Ito, J.K.; Brotheridge, C.M. Does supporting employees' career adaptability lead to commitment turnover, or both? Hum. Resour. Manag. 2005, 44, 5-19. [CrossRef]

46. Duarte, M.E.; da Silva, J.T.; Paixão, M.P. Career adaptability, employability, and career resilience in managing transitions. In Psychology of Career Adaptability, Employability and Resilience; Maree, K., Ed.; Springer: Cham, Switzerland, 2017; pp. 241-261.

47. Pulakos, E.D.; Arad, S.; Donovan, M.A.; Plamondon, K.E. Adaptability in the workplace: Development of a taxonomy of adaptive performance. J. Appl. Psychol. 2000, 85, 612-624. [CrossRef] 
48. Fouad, N.A. Work and vocational psychology: Theory, research, and applications. Annu. Rev. Psychol. 2007, 58, 543-564. [CrossRef]

49. Blustein, D.L. The Psychology of Working: A New Perspective for Career Development, Counseling, and Public Policy; Lawrence Erlbaum Associates: Mahwah, NJ, USA, 2006. [CrossRef]

50. Gottfredson, L.S. Circumscription and compromise: A developmental theory of occupational aspirations. J. Couns. Psychol. 1981, 28, 545-579. [CrossRef]

51. Blustein, D.L. The role of work in psychological health and well-being: A conceptual, historical, and public policy perspective. Am. Psychol. 2008, 63, 228-240. [CrossRef] [PubMed]

52. Duffy, R.D.; Blustein, D.L.; Diemer, M.A.; Autin, K.L. The psychology of working theory. J. Couns. Psychol. 2016, 63, 127-148. [CrossRef] [PubMed]

53. Cheung, F.; Ngo, H.Y.; Leung, A. Predicting work volition among undergraduate students in the united states and hong kong. J. Career Dev. 2018. [CrossRef]

54. Masdonati, J.; Schreiber, M.; Marcionetti, J.; Rossier, J. Decent work in switzerland: Context, conceptualization, and assessment. J. Vocat. Behav. 2019, 110, 12-27. [CrossRef]

55. Bouchard, L.M.; Nauta, M.M. College students' health and short-term career outcomes: Examining work volition as a mediator. J. Career Dev. 2018, 45, 393-406. [CrossRef]

56. Duffy, R.D.; Douglass, R.P.; Autin, K.L.; Allan, B.A. Examining predictors of work volition among undergraduate students. J. Career Assess. 2016, 24, 441-459. [CrossRef]

57. Duffy, R.D.; Bott, E.M.; Torrey, C.L.; Webster, G.W. Work volition as a critical moderator in the prediction of job satisfaction. J. Career Assess. 2013, 21, 20-31. [CrossRef]

58. Allan, B.A.; Autin, K.L.; Duffy, R.D. Examining social class and work meaning within the psychology of working framework. J. Career Assess. 2014, 22, 543-561. [CrossRef]

59. Autin, K.L.; Douglass, R.P.; Duffy, R.D.; England, J.W.; Allan, B.A. Subjective social status, work volition, and career adaptability: A longitudinal study. J. Vocat. Behav. 2017, 99, 1-10. [CrossRef]

60. Hayes, A.F. Introduction to Mediation, Moderation, and Conditional Process Analysis: A Regression-Based Approach; The Guilford Press: New York, NY, USA, 2013.

61. Chomeya, R. Quality of psychology test between likert scale 5 and 6 points. J. Soc. Sci. 2010, 6, 399-403.

62. Savickas, M.L.; Porfeli, E.J. Career adapt-abilities scale: Construction, reliability, and measurement equivalence across 13 countries. J. Vocat. Behav. 2012, 80, 661-673. [CrossRef]

63. Tak, J. Career adapt-abilities scale—-korea form: Psychometric properties and construct validity. J. Vocat. Behav. 2012, 80, 712-715. [CrossRef]

64. MacKinnon, D.P.; Coxe, S.; Baraldi, A.N. Guidelines for the investigation of mediating variables in business research. J. Bus. Psychol. 2012, 27, 1-14. [CrossRef] [PubMed]

65. Bagozzi, R.P.; Yi, Y. On the evaluation of structural equation models. J. Acad. Mark. Sci. 1988, 16, 74-94. [CrossRef]

66. Johnson, P.O.; Neyman, J. Tests of certain linear hypotheses and their application to some educational problems. Stat. Res. Mem. 1936, 1, 57-93.

67. Aiken, L.S.; West, S.G. Multiple Regression: Testing and Interpreting Interactions; Sage: Thousand Oaks, CA, USA, 1991.

68. Hayes, A.F. An index and test of linear moderated mediation. Multivar. Behav. Res. 2015, 50, 1-22. [CrossRef]

(C) 2019 by the author. Licensee MDPI, Basel, Switzerland. This article is an open access article distributed under the terms and conditions of the Creative Commons Attribution (CC BY) license (http://creativecommons.org/licenses/by/4.0/). 